\title{
Statistical evaluation of ozone concentrations on open plots in a submountain beech ecosystem in the Western Carpathians Mts.
}

\author{
D. Kellerová, R. Janík
}

Ing. Daniela Kellerová, Dr. Ing. Rastislav Janík, Institute of Forest Ecology of the Slovak Academy of Sciences, Štúrova 2,96053 Zvolen, Slovakia,kellerova@sav.savzv.sk, janik@savzv.sk

\begin{abstract}
Kellerová, D., Janík, R. 2012: Statistical evaluation of ozone concentrations on open plots in a submountain beech ecosystem in the Western Carpathians Mts. - Beskydy, $6(1): 59-66$

The research was conducted on two plots withoutforest cover situated in the Štiavnické vrchy (A) Mts and in the Kremnické vrchy (B) Mts (Western Carpathian region) and a plot covered with several-year-old naturally regenerated beech stand (C) in the Kremnické vrchy Mts. The highest average value of $71 \mu \mathrm{g} \mathrm{m} \mathrm{m}^{-3}$ was recorded in 2007 for

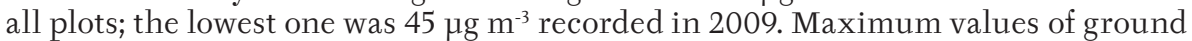
level ozone concentrations ranging from 124 to $144 \mu \mathrm{g} \mathrm{m} \mathrm{m}^{-3}$ were recorded in spring 2008 on all study plots. The values were displaying fairly high variability over the whore research period, with minima in years 2007 and 2008 on the plot covered with forest stand at the time. Statistically significant differences were distinct especially between the years 2007 and 2009.
\end{abstract}

Keywords: ground level ozone concentration, open plot, European beech, the West Carpathians Mts.

\section{Introduction}

In the recent years, the Central Europe has recorded noticeable changes to air pollution, both emissions and airborne pollutants. The effects of acid substances from the air on ecosystems have been reduced. However, there is another critical problem: ground level ozone occurring in increasing concentrations (Schmidt et al. 2008) and negatively influencing all components of the environment. The concentrations of this harmful substance in mountain and high-mountain areas are often higher than in urban agglomerations (Fleischer at al. 2005). During the years 1992-1996, the region of the Western Carpathians Mts was one of the most loaded in Europe, with the ozone levels often two times more than the critical limit (Kremler 2002, Bytnerowicz et al. 2004). The worsening of ozone conditions is associated with climatic changes characterised with temperature extremes and prolonged dry periods alternating with torrent rainfall events. In a long prospect, these conditions are forcing modification of the existing coniferous forest stands into mixed ones. A species promising to substitute in pure coniferous stands is European beech Fagus sylvatica (L.), significant from the viewpoint of wood production in Slovakia and sharing with $31.2 \%$ the highest proportion in the species composition of the Slovak forests. So, also in regions hitherto characteristic with coniferous forest cover, mixed forest stands are being shifted into the centre of interest (Hlásny et al. 2011).

Ozone, at presence of its precursors, has destructive effects on vegetation (Uhlírová et al. 2003, Günhardt-Goerg 2003). It affects biochemical processes in plant assimilatory organs and decelerates the rate of photosynthesis. The first symptoms of ozone damage to plants are, due to chlorophyll deficit, manifested as chlorosis and later as drying out the tissue (Mikkelsen et al. 1995). Later, the plants lose their woody mass which causes changes to the architecture of their aboveground parts. The slowed vital 
functions impair the plant's root system and the stability of the whole forest ecosystem. The priority in forest management as well as in forestryecological research is to preserve the forest stability. Apart from biotic and abiotic factors, the stabillity of ecosystems is significantly influenced by the management methods applied and by the processes of stand regeneration.

The aim of our research was to measure ground level ozone concentrations parallelly, at the same time and at the same altitude, and to evaluate the differences between the two localities. We supposed differences linked to the regional levels of airborne pollution. There was also monitored development of ozone concentrations in the beech stand that was changed in the study period from a forest stand to an open plot.

\section{Study area}

Our research ran on non forested plots in the Štiavnické vrchy Mts. (A) and the Kremnické vrchy Mts. (B) (Western Carpathian region), and on a plot in the Kremnické vrchy Mts. (C) from which the original beech stand was removed by gradual regeneration cutting.

The Kremnické vrchy Mts. and the Štiavnické vrchy Mts. are volcanic mountain massifs belonging to the Slovenské Stredohorie Mts. Their basins feature intensive agriculture, industry and landscape urbanisation.

The studied mountains belong into the forest zone with dominant occurrence of the third, oak-beech forest vegetation tier. The research plot in the Štiavnické vrchy Mts. is NW facing, while the plots in the Kremnické vrchy Mts. are oriented W. In context of the ground level ozone, this difference is noticeable. All plots are situated at adequate distances from the local and municipal sources, but they differ by their distance from the major pollution source. The plot in the Štiavnické vrchy Mts. is near to the important pollution source, the other two plots in the Kremnické vrchy Mts. are distant $18 \mathrm{~km}$.
The plot A in the Štiavnické vrchy and the plot B in the Kremnické vrchy are situated outside the stands. The plot $\mathrm{C}$ in the Kremnické vrchy Mts. was a former beech forest stand (rotation maturity) deforested by gradual cutting, being in 2009 a stand with natural regeneration. The plot characteristics are in Tab. 1.

The plot $C$ with natural regeneration in the Kremnické vrchy Mts. was cut at three phases, according to the common approach used in silvicultural practice. The second cutting intervention in spring 2004 (Barna 2004) had resulted in a stocking density of 0.5 , that means a stand with moderate intervention, and this status was still kept until 2007 and 2008. The third intervention applied in 2009 removed all trees of the parent stand (s.d 0.0). The light conditions on this plot facilitated development of natural regeneration, being in stage of seedlings after the final cutting.

\section{Method}

The ground level ozone $\left(\mathrm{O}_{3}\right)$ concentrations were measured by the sorption-accumulation method proposed by Werner (1991) during growing seasons (April-September) in years 2007-2009. The measured values were converted into the daily values.

Passive ozone samplers are installed in pairs on each plot. Their service is easy and the obtained results are compatible with continual analysers (Cox 2003, Bytnerowicz et al. 2004).

The principle of ozone amount determination is based on the selective reaction of an indigo layer applied on a filtration paper with the atmospheric ozone. The papers are exposed in the field for 7-10 days, and then they are extracted with ethanol in the laboratory. The reaction between indigo and ozone results in the creation of izatine, which is indicated by yellowing of the test papers. The content of izatine is determined using spectrophotometry at a wave-length of $408 \mathrm{~nm}$. The final value of the extinction is proportional to the izatine content and, as follows, also to the ozone content. The

Tab. 1: Basic characteristics of research plots in the Štiavnické vrchy Mts. and the Kremnické vrchy Mts.

\begin{tabular}{|c|c|c|}
\hline Characteristics & Štiavnické vrchy Mts. (A) & Kremnické vrchy Mts. (B, C) \\
\hline Coordinates & $\mathrm{N} 48^{\circ} 35^{\prime} 08^{\prime \prime}, \mathrm{E} 18^{\circ} 51^{\prime} 10^{\prime \prime}$ & $\mathrm{N} 48^{\circ} 38^{\prime} 10^{\prime \prime}, \mathrm{E} 19^{\circ} 04^{\prime} 08^{\prime \prime}$ \\
\hline Altitude & 470 & $470-510$ \\
\hline Aspect & NW & W \\
\hline Slope & $20^{\circ}$ & $5^{\circ}$ \\
\hline Geological substrate & Mull & Mull moder \\
\hline Rainfall & $700-750 \mathrm{~mm}$ & $510-1040$ \\
\hline Air temperature & $8.0-8.5 *$ & 8.2 \\
\hline Distance from emission source $\mathrm{km}$ & 1.5 & 18 \\
\hline
\end{tabular}

(Cicák, Mihál 2005) 
measured extinction values reflect the ozone totals according to the calibration curve. Ozone concentrations are given in standard units ppb per day or in $\mu \mathrm{g} \mathrm{m}^{-3}$. The equipment used to expose the indigo papers consists of a roofed stand and a perforated cylinder (a passive sampler) into which we placed the papers prepared in the laboratory. The detailed description is in Kellerová (2002).

Statistical processing of the results and testing of differences between the measured ozone concentrations were done with the software package Statistica.

\section{Results and Discussion}

The plot A in the Štiavnické vrchy Mts. exhibited the lowest mean value $54.4 \mathrm{\mu g} \mathrm{m}^{-3}$ (Tab. 2) over the whole study period. The maximum value, $142 \mu \mathrm{g} \mathrm{m}^{-3}$, was recorded in April 2008, the minimum, $28 \mu \mathrm{g} \mathrm{m}^{-3}$, in June 2008. The mean value on plot B in the Kremnické vrchy Mts. was 63.3, with maxima of $144 \mu \mathrm{g} \mathrm{m}^{-3} \mathrm{re}-$ corded repeatedly in spring 2008 and minimum of $22 \mathrm{\mu g} \mathrm{m}^{-3}$ recorded in the same year in August. In this year, at the same altitude, similar concentrations were obtained by Hůnová, et al. (2012). The plot C in the Kremnické vrchy Mts., modified gradually by cutting, had a mean concentration of 60, with maxima of $124 \mu \mathrm{g} \mathrm{m}^{-3}$ in April 2008 and minima of $18 \mu \mathrm{g} \mathrm{m}^{-3}$ in spring 2009. The concentration values on all plots were very similar, the trends in dynamics of the trapped ozone were not easy to discern. The cause may have been in the relatively short research period or in the rather high variability: $48.42 \%$ on plot A in the Štiavnické vrchy Mts., $46.48 \%$ on plot B in the Kremnické vrchy Mts. and $42.84 \%$ in natural regeneration on plot $C$ in the Kremnické vrchy Mts. Important drivers were climatic, meteorological and anthropic factors (Kellerová, Janík 2006, 2009) and geographic aspect. Somewhat higher average values in the Kremnické vrchy Mts. compared to the Štiavnické vrchy Mts. may be due to SW aspect of plots B and C (Hůnová, et. al. 2007). The descriptive statistic parameters are in Tab. 2

The Central European sub-mountain, equally as high-mountain zones is showing two maxima in a year: the first generally in spring (April, May), the second in summer (July, August, Report on the Quality of Environment of SR 2010). The Figures show evidence for spring maxima in Štiavnické (A) and Kremnické vrchy (B, C) Mts. in May 2007 and in April 2008. An exception was year 2009 with autumn maximum in the Kremnické vrchy Mts. (Fig. 1).

Apart from spatial variability, there was evidence for time variability. Fig. 2 demonstrates decreasing ozone concentration values on all plots. The highest average value for all plots was $71 \mu \mathrm{g} \mathrm{m}^{-3}$, measured in the year 2007; the lowest was $45 \mu \mathrm{g} \mathrm{m}^{-3}$ measured in the year 2009.

Differences in ground level ozone concentrations significant at $p<0.01$ were detected for plot A in the Štiavnické vrchy Mts. in 2007 and plots B, C in the Kremnické vrchy Mts. in 2009; and for plots B and C in between the years 2007 and 2009 (Kellerová, Janík 2006, 2009).

Tab. 2: Descriptive statistics of groundlevel ozone concentrations on experimental plots in the Štiavnickévrchy Mts. and Western Carpathians Mts. in years 2007-2009.

\begin{tabular}{lccc}
\hline Statistical parameters & $\begin{array}{c}\text { Open plotin the } \\
\text { Stiavnické vrchy Mts. }\end{array}$ & $\begin{array}{c}\text { Open plot in the } \\
\text { Kremnické vrchy Mts. }\end{array}$ & $\begin{array}{c}\text { Forest stand in } \\
\text { Kremnické vrchy Mts. }\end{array}$ \\
\hline Valid & 18.0 & 18.0 & 18.0 \\
Mean & 57.4 & 63.3 & 60.0 \\
Geometric mean & 2.37 & 56.73 & 54.66 \\
Sum & 1034.00 & 1139.00 & 1078.00 \\
Minimum & 28.00 & 22.00 & 18.00 \\
Maximum & 142.00 & 144.00 & 124.00 \\
Lower quartile & 36.00 & 44.00 & 42.00 \\
Upper quartile & 64.00 & 80.00 & 76.00 \\
Range & 114.00 & 122.00 & 106.00 \\
Variance & 773.56 & 865.15 & 658.11 \\
Standard deviation & 28.81 & 29.41 & 25.65 \\
Standard error & 6.55 & 6.93 & 6.05 \\
Coeff. of variation & 49.42 & 46.48 & 42.84 \\
\hline
\end{tabular}



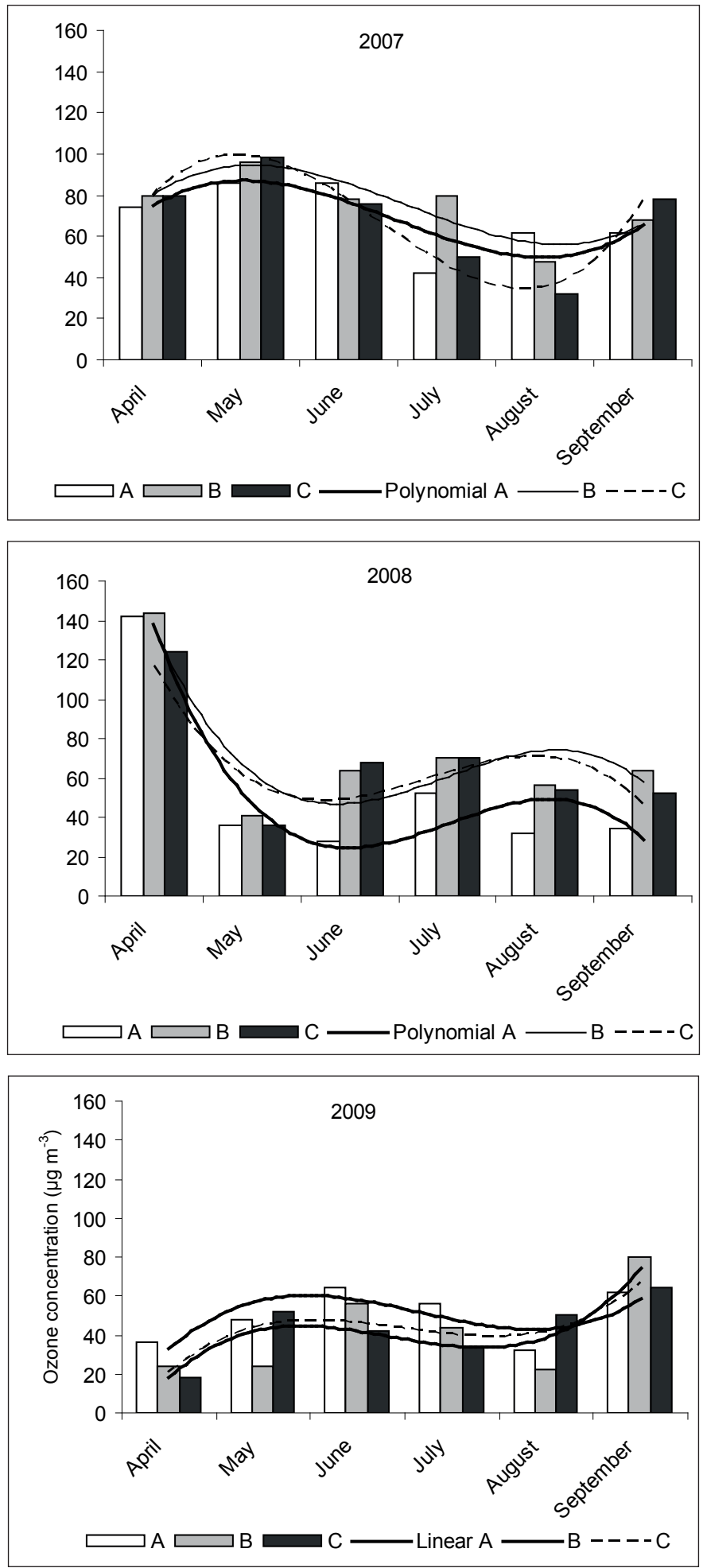

Fig. 1: Mean monthly ozone concentrations in the Štiavnické vrchy Mts. (A) and the Kremnické vrchy Mts. (B, C). 


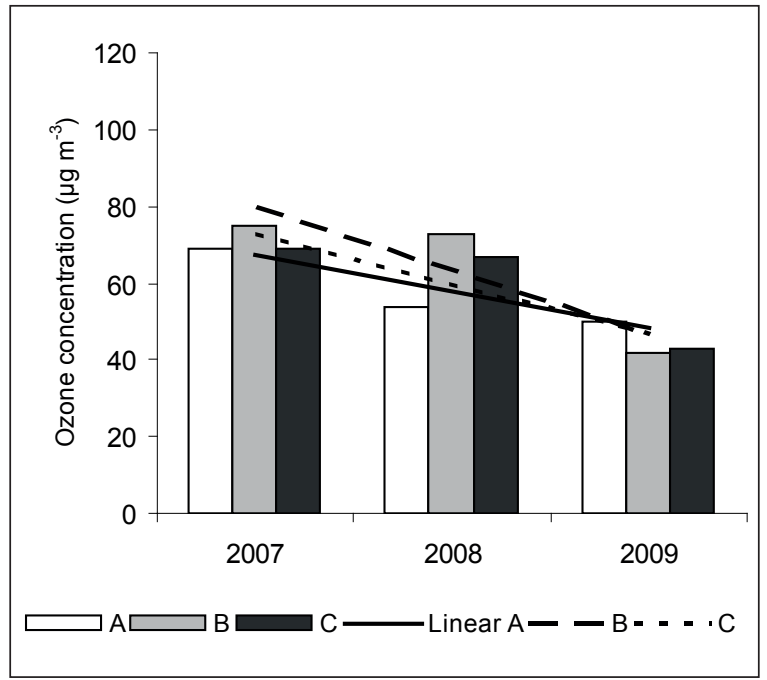

Fig. 2: Mean annual concentration values of ground level ozone concentrations calculated from summer monthly concentrations on research plots in the Štiavnické vrchy Mts. (A) and in the Kremnické vrchy Mts. (B, C).

Tab. 3: Mean monthly temperature and precipitaion on research plots in the Kremnické vrchy Mts. and in the Štiavnické vrchy Mts. in years 2007-2009.

\begin{tabular}{|c|c|c|c|c|c|c|}
\hline Year & 2007 & 2008 & 2009 & 2007 & 2008 & 2009 \\
\hline \multicolumn{7}{|c|}{ Temperature $\left({ }^{\circ} \mathrm{C}\right)$} \\
\hline Month & \multicolumn{3}{|c|}{ Štiavnické vrchy Mts. } & \multicolumn{3}{|c|}{ Kremnické vrchy Mts. } \\
\hline IV & 11.9 & 10.7 & 13.9 & 10.8 & 9.8 & 12.8 \\
\hline $\mathbf{V}$ & 16.2 & 15.6 & 15.7 & 15.4 & 14.9 & 15.5 \\
\hline VI & 19.7 & 19.5 & 17.4 & 19.0 & 18.9 & 16.9 \\
\hline VII & 20.9 & 16.6 & 21.3 & 20.4 & 19.4 & 20.8 \\
\hline VIII & 20.0 & 19.0 & 20.5 & 19.7 & 19.2 & 20.3 \\
\hline IX & 12.5 & 13.6 & 16.6 & 11.9 & 13.6 & 16.1 \\
\hline IV-IX & 16.9 & 16.3 & 17.6 & 16.2 & 16 & 17.1 \\
\hline Year & 10.5 & 11.8 & 11.6 & 9.6 & 9.7 & 9.5 \\
\hline \multicolumn{7}{|c|}{ Precipitation (mm) } \\
\hline IV & 3 & 32 & 8 & 0 & 40 & 9 \\
\hline $\mathbf{V}$ & 63 & 38 & 38 & 135 & 35 & 74 \\
\hline VI & 69 & 65 & 71 & 35 & 130 & 112 \\
\hline VII & 33 & 125 & 57 & 29 & 124 & 52 \\
\hline VIII & 126 & 38 & 46 & 72 & 24 & 40 \\
\hline IX & 60 & 34 & 43 & 50 & 36 & 28 \\
\hline IV-IX & 354 & 332 & 263 & 321 & 389 & 315 \\
\hline Year & 666 & 647 & 666 & 671 & 725 & 784 \\
\hline
\end{tabular}


Fig. 2 also shows a drop in ozone concentrations in year 2009 on all three plots - due to a massive, long-settled anticyclone.

Despite there had not been recorded an increase in the ozone concentrations over the study period, the occurrence of extreme values still represents a serious risk. The episodes with high ozone concentrations arise due to the local and regional emissions of ozone precursors, and in Slovakia also due to the transboundary pollution (Závodský et al. 2001, Liu et al. 2006, Zapletal, Chroust 2007). The ozone formation in Slovakia is by $10 \%$ due to the local sources, and mostly at presence of advection. The main local driver is the fast growing car traffic.

There were not detected remarkable inter-annual differences in the mean ozone concentratins values calculated for the whole SR territory: 62, 61 and $62 \mu \mathrm{g} \mathrm{m}^{-3}$ in years 2007, 2008 and 2009 (Regional Programme aimed at Improvin Air Quality in SR for ground level ozone 2010). The measured ozone concentrations demonstrate absence of an unequivocal trend, probably due to effects of multiple environmental factors.

Gardner and Dorling (2000), Sundberg et al. (2006) have shown that the inter-annual variation in ozone concentrations linked to meteorological factors may be much more pronounced than the variation linked to the concentrations of ozone precursors. This has also been confirmed by Finlayson-Pitts, Pitts (2000) who claim that the most favourable conditions for photo-chemical ozone formation are in general: high temperature, high solar radiation intensity, absence of atmospheric precipitation, low wind speed and low relative air humidity. For completeness, the basic climatic characteristics for the study localities are summarised in Tab. 3.

\section{References}

BARNA, M. 2004: Adaptation of European beech (Fagus sylvatica L.) to different ecological conditions: leaf size variation. Polish Journal of Ecology, 52: 35-45.

Bytnerowicz, A., Godzik, B., Grodzinska, K., Fraczek, W., Musselman, R., Manning, W., Badea, O., Popescu, F., Fleischer, P. 2004: Ambient ozone in forest of Central Eastern $\mathrm{Eu}$ ropean mountains. Environmental Pollution, 130: 5-16.

Finlayson-Pitts, B. J, Pitts, J. N. JR. 2000: Chemistry of the Upper and Lower Atmosphere. Academic Press. San Diego, 969 pp.

\section{Conclusion}

In the recent years, ecological situation in Central Europe has been showing positive trends; mainly thank to the improved situation in airborne pollutants in terms of the main emission parameters.

The situation in ozone formation has not stabilised yet; the development trend is not possible to outline unambiguously. The values measured on all plots in the Štiavnické vrchy Mts. and the Kremnické vrchy Mts. were displaying high variability over the whole study period. The relatively lowest variability values were obtained for the formerly forested plot in the Kremnické vrchy Mts. (C).

The testing revealed statistically significant differences, especially between the years. Episodes with high ozone concentrations have negative effects on all plots discussed in this study.

Beech, together with spruce and fir, is a very sensitive species. However, in the next years, it is assumed keeping its dominant place among woody plants of Central Europe, despite the anticipated climate change..

\section{Acknowledgement:}

This work was supported by the Scientific Grant Agency of the Ministry of Education of the Slovak Republic and the Slovak Academy of Sciences (Projects No. 2/0055/10, 2/0068/10, 2/0034/10, 2/0041/13). We also acknowledge D. Kúdelová for preparing the English text.

CicÁK, A., MinÁL, I. 2005: Development of beech necrotic disease in the growing phase of maturing stand under air pollution stress. Journal of Forest Science, 51 (3): 101-107.

Cox, R. M. 2003: The use of passive sampling to monitor forest exposure to $\mathrm{O}_{3}, \mathrm{NO}_{2}, \mathrm{SO}_{2}$ : a review and some case studies. Environ. Poll., 126 (3): 301-311.

Fleischer, P., GodziK, B., BičÁrová, S., BytneroWICZ, A. 2005: Effects of air pollution and climate change of forests of Tatra Mountains, Central Europe. Plant responses to air pollution and global change, Springer-Verlag Tokyo, 111-121. 
Gardner, M, W., Dorling, S. R. 2000: Meteorologically adjusted trends in UK daily maximum surface ozone concentrations. Atmospheric Environment, 34: 171-176.

Gúnthardt-Goerg, M. S., Vollenweider, P. 2003: Microscopy for differential diagnostic of foliarozone symptons. Prezentation on the $4^{\text {th }} \mathrm{In}$ ternational training Course Ozone Visibly Injury. Switzerland/Italy 25-27 th August, 2003.

Hlásny, T., Turčáni, M., Fabrika, M., Baláž, P., SEDMÁK, R. 2011: Očakávané dopady zmeny klímy na bukové porasty Slovenska. [Anticipated climate change impacts on beech stand in Slovakia]. In: Barna, M., Kulfan, J., Bublinec, E. (eds.): Buk a bukové ekosystémy Slovenska. Veda SAV Bratislava, 621-634.

HưnOvâ, I., SRnĚNSKÝ, R., KoŽElKovÁ, K. 2007: Využití pasivních dosimetrů pro vymezení rizikových oblastí z hlediska potenciálního poškození vegetace přízemním ozonem. [Application of diffusive samplers for risk assesment regarding the potential impacts of surface ozone on vegetation]. In: BLÁHA, L. (ed.): Vliv abiotických a biotických stresorü na vlastnosti rostlin. Zborník, VÚRV v.v.i Praha - Ruzyně, ČZU v Praze, 362-367, ISBN: 978-80-213-1621-8

Hủnová, I., Horálek, J., Schreiberová, M., Zapletal, M. 2012: Ambient ozone exposure in Czech forests: A-GIS based approach to spatial distribution assessment. The Scientific World Journal, 123760, doi:10.1100/2012/123760.

Kellerová, D. 2002: Surface ozone at the beech ecological experimental station. Kremnické vrchy Mts. Ekológia (Bratislava), 21: 26-32.

KellerovÁ, D., Janík, R. 2006:Air temperature and ground level ozone concentration in submountain beech forest (Western Carpathians, Slovakia. Pol. J. Ecol., 54 (3): 505-509.

KellerovÁ, D., Janík, R. 2012: Temporal and spatial trends and specific airborne pollutant quantities in beech stands modified by regeneration cuts. Ekológia (Bratislava), 31 (2): 150-157.

Kremler, M. 2002: Daily and annual course of surface ozone concentrations at Slovak monitoring station. Meteorological Journal, 7: $29-36$.

Liu, X., Chance, K., Sioris, Ch. E., Kurosu, T. P., Spurr, R. J. D., Martin, R. V., Fu, T.M., Logan, J. A., Jacob, D. J., Palmer, P. I., Newcgurch, M. J., Megretskaia, I. A., Carfield, R. B. 2006: First directly retrieved global distribution of tropospheric column ozone from GOME:
Comparison with the Geos-CHEM model. Journal of Geophysical Research, 111: 1-17.

Mikkelsen, T.N., Dodell, B, Lütz, C. 1995: Changes in pigment concentration and composition in Norway spruce induced by longterm exposure to low levels of ozone. Environmental Pollution, 87: 197-205.

Smidt, S., Spangl, W., Nagl, Ch. 2008: Trends of air pollution in Austrian forest areas. The Austrian Journal of Forest Science, 1: 27-38.

Sundberg, J., Karlsson, P. E., Schenk, L., Pleijel, H. 2006: Variation in ozone concentration in relation to local climate in West Sweden. Water, Air and Soil Pollution, 173: 339-354.

Uhlî́rovâ, H., HƯNovÁ, I., Novotný, R., LomsKÝ, B., HorÁleK, J. 2003:Oxidačný stres v podmínkách horských smrčin. Zprávy lesnického výzkumu, 48: 200-205.

Werner, H. 1991: Methodische Details für das Ozonmonitoring mit Indigopapieren. II Workshop zum Thema Integrale Messmethoden, Salzburg, AGRE ALP, AGRE ALPENAGRIA, 110 pp.

Zapletal, M., Chroust, P. 2007: Deposition flow of ozone into forest ecosystems across the Czech Republic territory. [Depoziční tok ozonu do lesních ekosystémů na území ČR]. Ochrana ovzduší, 3: 20-26.

ZĀvodský, D., Medveň, M., Ďurec, F. 2001: Atmospheric chemistry and air pollution modelling. Leonardo da Vinci Programme, Vysokoškolská učebnica, Matej Bel University, Banská Bystrica, 127 pp. 
